\title{
PENINGKATAN PRODUKSI TEKNOLOGI TEPAT GUNA MESIN CETAK KUE JEPIT DOLAR PADA UKM
}

\author{
Siswadi ${ }^{1)}$,Wahyu Nugroho ${ }^{2)}$, Heru Siswanto ${ }^{3)}$, \\ ${ }^{1,2,3)}$ Program Studi Teknik Mesin Fakultas Teknik, Universitas Wijaya Putra \\ 1)e-mail:siswadi@uwp.ac.id
}

\begin{abstract}
ABSTRAK
Sebagian besar Pengusaha kue jepit dolar untuk masih menggunakan sistem manual, mencetaknya dengan menggunakan tangan, sehingga kapasistas produksinya relatif sangat rendah. Guna mengatasi permasalahan tersebut dari Tim PKM Fakultas Teknik Universitas Wijaya Putra, 1) Merancang, membuat mesin pencetak kue jepit dolar dengan menerapkan TTG supaya hasil produksinya lebih banyak.dan 2) Memberikan penerapan menajemen Pemasaran supaya ke dua Mitra mengerti tentang bagai mana manajemen pemasaran yang baik. Hal ini berdampak pada peningkatan produktivitas pada mitra pengusaha Pengusaha kue UD, Lumayan alamat, di daerah Sawo Cangkring RT03/RW03, Kec.Wono Ayu, Kab.Sidoarjo dan Mitra pengusaha kue jepit dolar diharapkan melalui mesin pencetak kue jepit dolar ini ouput yang dihasilkan dapat membantu untuk peningkatan produktivitasnya dan juga berpengaruh pada kesejateraan mereka. Hasil yang didapat dari kegiatan ini:1) Mesin pencetak kue jepit dolar ini dapat mempercepat proses pembuatanya dengan kualitas baik. 2) keberadaan mesin pencetak kue jepit dolar ini dapat meningkatkan produktivitas mitra menjadi 3 kali, yang sebelumnya hanya 36 dos menjadi 108 dos kue jepit dolar /hari 3) Output yang dihasilkan lebih berkualitas dan lebih sempurna, 4) meringankan beban tenaga kerja karena tenaga manusia tergantikan oleh mesin. Tentang manajemen pemasaran ini diterapkan maka, dua mitra dapat menambah pelanggan, serta mengatur cara kerja pemasarannya.
\end{abstract}

Kata kunci: Membuat Mesin TTG Pencetak Kue Jepit Dolar, dan memberikan Manajemen Pemasaran 


\section{PENDAHULUAN}

kue jepit dolar merupakan salah satu makanan camilan paling digemari oleh masyarakat Indonesia termasuk dikota Surabaya-Jawa Timur. Selera masyarakat tidak pernah jenuh terhadap makanan kue jepit dolar. Segmentasi makanan kue jepit dolar tidak hanya didominasi oleh kaum remaja dan anak-anak, tetapi kalangan tua juga menggemarinya. kue jepit dolar ini untuk memenuhi permintaan konsumen yang selalu meningkat, pengusaha kue jepit dolar dituntut terus meningkatkan produktivitas dan kualitas produknya.

Pemilihan Mitra Kerja didasarkan hasil 2 (dua) kali observasi oleh Tim Pengusul, yang kualifikasinya menurut Tim Pengusul dipandang memenuhi syarat sesuai Panduan Program Pengabdian Kepada Masyarakat. Kedua Pegusaha kue jepit dolar dibawah ini dipandang layak diajak kerjasama untuk melaksanakan. Program PKM. Adapun 2 Pengusaha kue jepit dolar yang menjadi mitra PKM ini adalah sebagai berikut:

1) Pengusaha kue jepit dolar" UD, Lumayan yang beralamatkan Sawo Cangkring RT03/RW03, Kec.Wono Ayu, Kab.Sidoarjo ini berdiri sejak tahun 2003.

2) Pengusaha kue jepit dolar" UD. Sinar Jaya beralamat di Sawo Cangkring RT01/RW04, Kec.Wono Ayu Kab, Sidoarjo berdiri tahun 2003

Berdasakan analisis situasidi atas, maka dapat dibuat perumusan masalah sebagaiberikut:

a. Pencetak kue jepit dolar yang dimiliki oleh Mitra pengusaha kue jepit dolar ini tergolong manual, sehingga produktivitas untuk menghasilkan kue jepit dolar masih rendah. Hal ini menyebabkan pendapatan mitra pengusaha kue jepit dolar belum mengalami peningkatan. Setelah Kehadiran Program PKM usaha mikro kue jepit dolar ini permasalahan semua dapat diatasi dan bisa dan pengahasilan kue jepit dolar akan lebih meningkat.

b. Mitra pengusaha kue UD, Lumayan dan UD. Sinar Jaya belum mengenal teknologi tepat guna untuk memproduksi kue jepit dolar. Hal ini menyebabkan pendapatan mitra pengusaha kue jepit dolar Lumayan dan Mitra pengusaha kue jepit dolar Sinar Jaya belum mengalami peningkatan. Dengan usaha tim program PKM usaha Mikro Sinar Jaya ini setelah memberikan pelatihan manajemen produksi dan pelatihan perawatan mesin maka para mitra dapat meningkatkan hasil produksinya yang jelas akan meningkat pendapatan ekonomimya.

Adapun tujuan kegiatan PKM bagi Masyarakat ini adalah membantu para mitra pengusaha kue jepit dolar untuk meningkatkan produktivitas kue jepit dolar dengan cara merubah pola produksi dari cara manual yang digunakan selama ini menjadi cara mesinisasi dengan memanfaatkan teknologi tepat guna. Penggunaan Teknologi Tepat Guna yang dimaksud adalah Mesin Pencetak kue jepit dolar kerena selama ini para mitra pengusaha kue jepit dolar masih menggunakan cara menual dengan menggunakan tenaga tangan. Hasil PKM Mikro usaha kue jepit dolar ini telah berhasil dengan meningkatkan pendapatan meningkatkan kue jepit dolar, juga hasilnya didapatkan lebih baik..

Kegiatan Pengabdian kepada Masyarakat (PKM diharapkan mendapatkan manfaat yang dapat dirasakan bagi mitra usah kue jepit dolar di Sidoarjo. Adapun manfaat kegiatan pengabdian ini yang dapat dirasakan bagi mitra usaha kue jepit dolar adalah sebagai berikut:

a. Meningkatnya produktivitas mitra usaha kue jepit dolar 
b. Meningkatnya pendapatan para mitra pengusaha kue jepit dolar

c. Para mitra pengusaha kue jepit dolar dapat mengenal dan menerapkan Teknologi Tepat Guna (TTG) mesin pencetak kue jepit dolar

d. Menghasilkan model penerapan Teknologi Tepat Guna (TTG ) Mesin pencetak kue jepit dolar diaplikasi secara luas oleh mitra usaha kue jepit dolar.

Output yang dihasilkan dari kegiatan PKM meliputi output secara ekonomi produk. Pada saat ini para mitra usaha kue jepit dolar ratarata belum mempunyai mesin pencetak kue jepit dolar semuanya manual yang kapasitas produksinya hanya 36 dos kue jepit dolar per hari sekarang ini, Dengan hasil kegiatan Program PKM ini maka hasilnya dapat meningkat menjadi 108 dos kue jepit dolar per hari. Berarti dengan waktu yang jauh lebih singkat produksinya dapat ditingkatkan 3 kali lipat per hari. Berarti tiap hari hasil produksi kue jepit dolar lebih banyak, sehingga pendapatan secara ekonomi akan lebih meningkat.

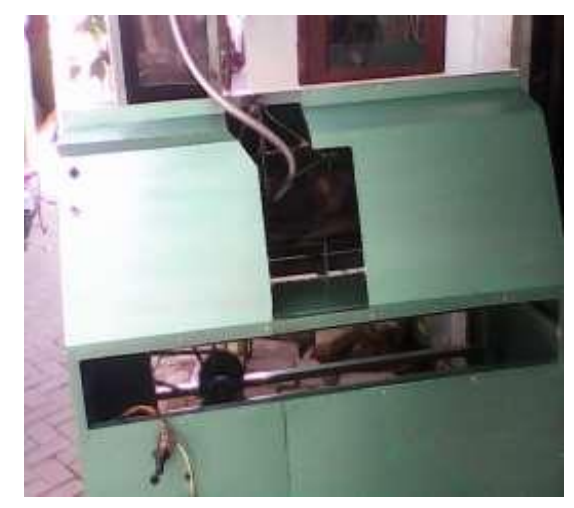

Gambar 1. Hasil Mesin TTG Kue Jepit Dolar

\section{METODE PELAKSANAAN}

Metode yang digunakan adalah pembuatan mesin pencetak kue jepit dolar dan Manajemen Pemaaran. Proses pencetakan kue jepit dolar adalah; pembuatan pencetak kue jepit dolar dengan menggunakan mesin pencetak, di lengkapi dengan motor listrik sebagai pengeraknya, bahkan dengan berbagai macam roda gigi dan rantai, akan menggerakkan roda gigi lainnya guna memutar dan dilengkapi sensor umtuk mengeluarkan adonan kue jepit dolar secara otomatis

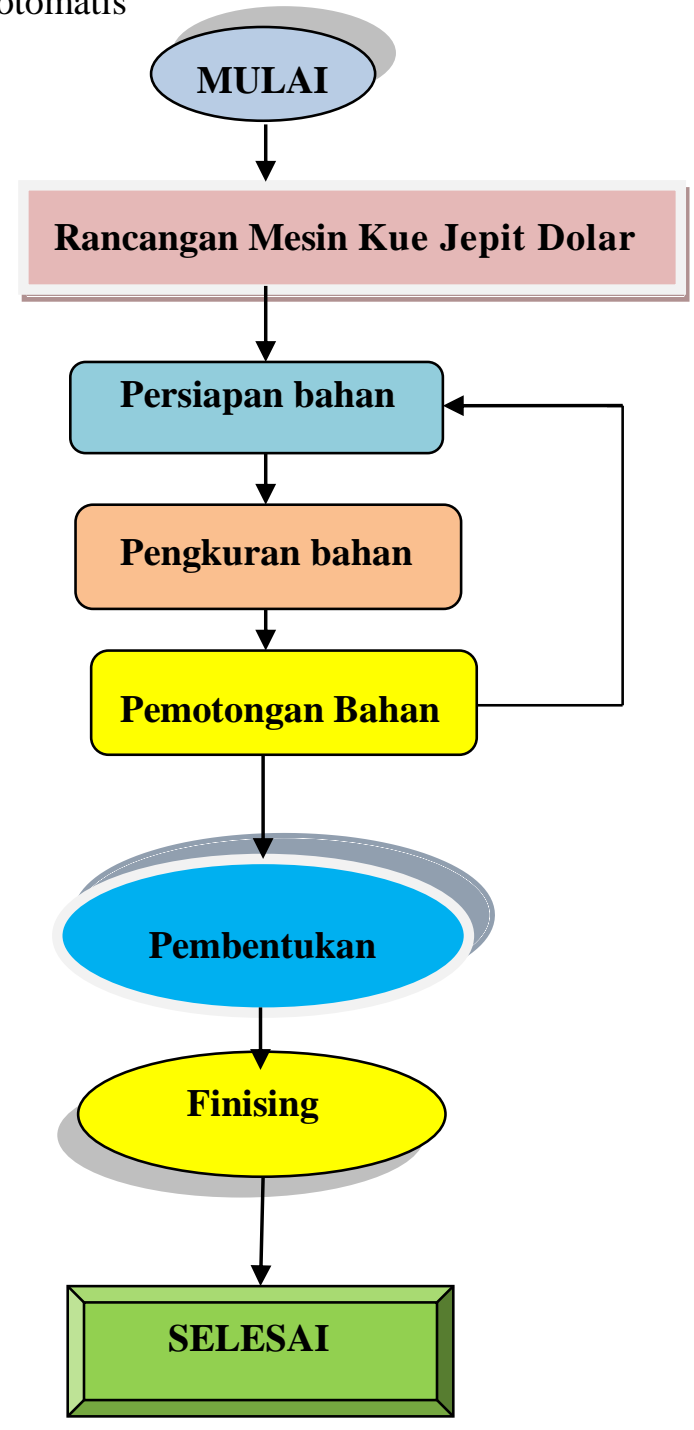

Gambar 2. Diagram Alir Penelitian

Pencetakan kue jepit dolar dengan menggunakan mesin pencetak kue jepit dolar ini pengoperasiannya sangat mudah, dan hasilnya sangat berlipapat, di banding mencetak kue jepit dolar dengan menggunakan sistem manual, cara pengoperasiannya hanya tinggal memasukkan adonan yang sudah jadi kedalam corong mesin dan mengatur dan menyetel bentuknya bulatnya, setelah pas ukuran maka mesin 
dijalankan secara kontinyu, dan apabila mencetaknya kurang pas maka harus di ulang sampai dengan pas untuk bulatnya, sedangkan bagian bawah dari lubang keluarnya kue jepit dolar pada mesin harus di beri api dari pipa LPG, adonan yang keluar dari corong secara otomatis kemudian adonan disemprotkan ke cetakan kue jepit dolar sebanyak 1 sendok teh tiap cetakan maka cetakan itu berputar keadaan panas dan adonan memjadi opak lempengan bulat yang berdiameter $5 \mathrm{~cm}$ dengan diberi garis-garis supaya kelihatannya lebih menarik.

Mutu dan dan hasil yang diperolehnya sangat jauh berbeda dengan sistem manual, kerena sitem manual tentang bentuk tidak sama dan beratnya pun tidak sama, kalau menggunakan mesin pencetak kue jepit dolar ini tentang bentuknya keluarnya akan sama dan beratnya juga sama, tentang perbandingan hasil yang diperoleh antara sistem manual dengan menggunakan mesin bisa mencapai 3 kali per hari mencetak kue jepit dolar.

Pendampingan,perlu diadakan, dikarenakan pemakaian mesin harus di latih dan di ajari tentang cara pengoperasikan mesin, juga di beri cara merawat mesin supaya mesin pencetak kue jepit dolar Pendampingan dilaksaksanakan oleh Team PKM Mikro kue jepit dolar kepada mitra pengusaha kue jepit dolar untuk 2 orang.

Penyuluhan tentang cara peningkatan pelanggan dan keuangannya, Dari team PKM Mikro usaha kue jepit dolar dengan memberikan contoh -contoh dan memberikan materi untuk di pakai pegangan bilamana terdapat kesulitan, baik bidang tatacara menarik pelanggan dan bagaimana cara untuk membukukan keuangan yang baik.

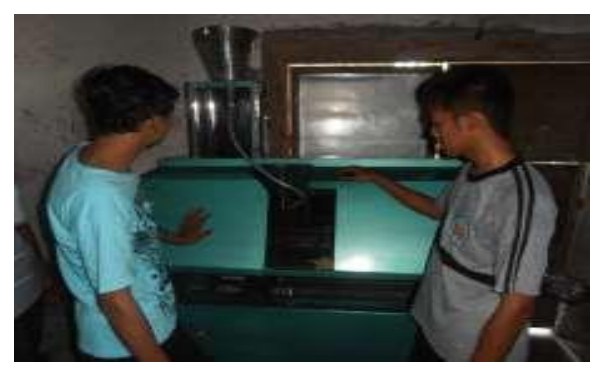

Gambar 3. Pengoperasian Mesin

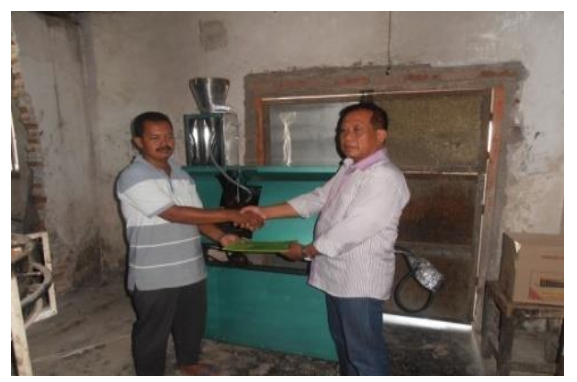

Gambar 4. Mencetak Kue Jepit Dolar

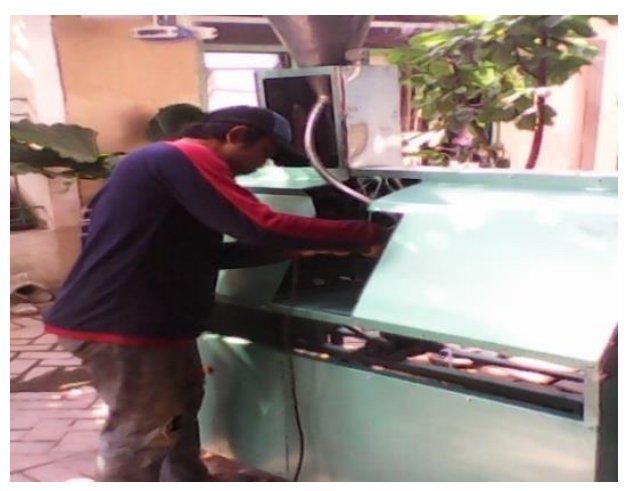

Gambar 5. Cara Perawatan Kue Jepit Dolar

\section{HASIL DAN PEMBAHASAN}

Dengan data-data yang sudah ada maka data tersebut telah diolah oleh team PKM Mikro Usaha kue jepit dolar kemudian merumuskan untuk tercapai tujuan akhir, yaitu bagaimana cara membuat mesin pencetak kue jepit dolar dan meningkatkan hasil produksi kue jepit dolar dengan menggunakan mesin TTG serta menambah pelanggan dan meningkatkan perekonimiannya untuk para mitra usaha kue jepit dolar .Pengabdian kepada masyarakat program pkm bagi Masyarakat ini dilakukan diawali dengan kegiatan survey lapangan selama 3 (tiga) hari.. Kegiatan survey tersebut dilakukan untuk mendapatkan data awal tentang mitra.. Akhir dari kegiatan Program PKM Usaha Mikkro kue jepit dolar ini telah mengadakan demo/ percobaan mesin pencetak kue jepit dolar

Demo/Percobaan untuk mesin dengan teknologi tepat guna (TTG) mesin kue jepit dolar ini supaya hasilnya dapat dilihat baik tidaknya. Pada kegiatan tersebut juga 
termasuk sosialisasi penggunaan mesin pencetak kue jepit dolar. Pelatihan untuk Mitra dengan memperhatikan penjelasan Team PKM mikro usaha kue jepit dolar dengan pemberian masukan tentang manajemen pemasaran, sebab banyak yang belum mengerti tentang bagaimana cara pemasaran yang baik. Dengan adanya tim PKM ini memberikan penjelasan maka dari mitra baru tahu bagaimana cara pemasaran produk tersebut, sehingga para mitra tersebut dapat menerima. Produksi kue jepit dolar ini masih menggunakan sistem manual, sedangkan hasil yang di perolehnya sangat rendah dan mutunya kurang baik, karena membuatnya dengan menggunakan tangan.

Setelah ada Tim PKM ini mitra dengan pola baru dengan menggunakan mesin pecetak kue jepit dolar ini maka hasil produksinya meningkat dan mutunya sangat baik, dan juga mesin ini selain bisa mencetak kue jepit dolar bisa mencetak soses.Maka Tim PKM usaha mikro kue jepit dolar ini jelas mengangkat mitra terutama Peningkatan produk dengan hasil yang baik, dan juga akan meningkatkan tetang ekonomi untuk mitra tersebut.

Hasil penyuluhan dan pelatihan manajemen Pemasaran, para mitra mendengarkan penjelasan tim PKM. Bahkan ada pertanyaan terkait dengan materi yang disajikan, misalnya masalah pemasaran, desain produk penggorengannya dan kendala teknologi. Berdasarkan hasil tanya jawab didapat gambaran keberadaan mitra memproduksi kue jepit dolar dengan cara Teknologi modern Mitra saat ini telah memahami tentang; bagaimana pemasaran produk kue jepit dolar dan mengerti tetang bagaimana meningkakatkan produksi pentol, serta bagiamana manajemennya yang harus di lakukan, serta pengelolaan secara higenis.Dari hasil penjelasan dan demo tersebut oleh Mitra dan Instruktur yang dibantu oleh mahasiswa fakultas teknik.saat ini mitra sudah fahan dan mengerti dan dilaksanakan. Pelaksanaan kegiatan PKM Fakultas Teknik Universitas Wijaya Putra dalam membantu pihak mitra telah mampu menyelesaikan sebagian masalah dengan baik dan benar. Dua unit mesin teknologi tepat guna pencetak kue jepit dolar telah dirancang dan dibuat oleh Tim Pelaksana PKM Universitas Wijaya Putra dengan pertimbangan dan masukan dari pihak mitra, akhirnya dapat terselesaikan dengan baik. Dua mesin pencetak kue jepit dolar ersebut diserahkan ke mitra dalam dua tahap penyerahan, mesin pertama diserahkan pada tanggal 18 Juli 2015. Kemudian penyerahaan mesin yang kedua pada bulan 09 November 2015.

\section{Pendampingan dan Pelatihan tentang Manajemen Pemasaran}

Dengan pelatihan tentang manjemen Pemasaran ini maka, Tim PKM usaha mikro kue jepit dolar in memberikan pelatihan untuk 2 orang dari mitra Usaha kue jepit dolar

Manajemen Pemasaran ini belum mengenal dan bagai mana cara memesarkan yang baik dan sehingga kue jepit dolar bisa laku dan mendapat konsumen yang banyak , selanjutnya dengan kedaan sekarang; Manjajemen Pemasaran: dengan diberi pelatihan dan pendampingan: maka saat ini para mitra kue jepit dolar UD, Lumayan ini memahami dan mempunyai Pengetahuan tentang manajemen Pemasaran .

\section{Pendampingan Tentang Perawatan Mesin}

Perawatan Mesin pencetak kue jepit dolar ini perlu dilakukan, sehingga mesin tetap terjaga jangan sampai rusak, oleh karena itu perlu diadakan pendampingan dan pelatihan perawatan mesin terhadap mitra usaha kue jepit dolar Sebelumnya, Mitra mencetak kue jepit dolar masih manual (mencetak kue jepit dolar menggunakan tangan ) jadi tidak perlu adanya perawatan mesin. Dengan kedaan sekarang, Mitra saat ini mencetak kue jepit dolar sudah menggunakan Mesin pencetak. Maka dalam saat ini peru adanya perawatan mesin, juga pengoperasionalkan mesin secara baik dan benar.

Monitoring \& Evaluasi Produksi 
Memproduksi kue jepit dolar perlu adanya pengamatan dan pelatihan kerja terhadap mesin pencetak kue jepit dolar, sehingga produksi kue jepit dolar dengan hasil yang baik dan tidak banyak yang rusak

Sebelumnya, Membuat kue jepit dolar pada walnya tidak memperhatikan tentang Adonannya serta, hasil produksi kue jepit dolar yang di cetak atau di buat(dengan sistem manual

Kedaan sekarang, Mitra saat ini bisa mengukur tentang adonan serta hasil catakan kue jepit dolar dengan disesuaikan ukuran atau diameter Opak Jepit yang dikehendaki.untuk ukr $2,5 \mathrm{~cm}$ atau $3,5 \mathrm{~cm}$ Karena mitra menggunakan mesin pencetak kue jepit dolar

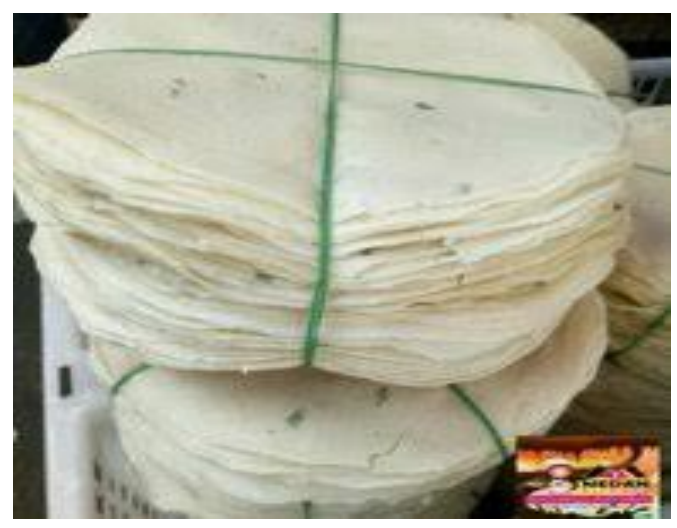

Gambar 6. Produk kue jepit dolar

$*$

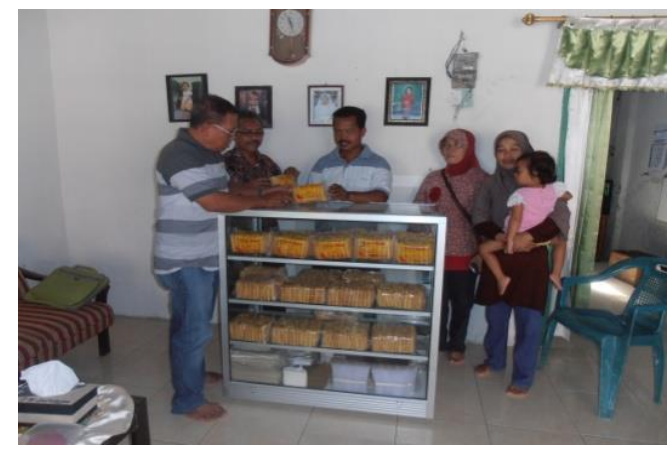

Gambar 7. Hasil Mesin TTG kue jepit dolar

\section{SIMPULAN DAN SARAN Simpulan}

Bahwa Program PKM Usaha Mikro kue jepit dolar di Sidoarjo ini, penyelenggaraan pembuatan mesin pencetak kue jepit dolar dengan menggunakan Teknologi Tepat Guna ( TTG ) dari Tim PKM telah memberikan kesimpulan tentang; manajemen Peningkatan produktivitas dengan menggunakan sistem manual dan di rubah menjadi sitem teknologi yang modern dengan menggunakan mesin pecetak kue jepit dolar. Tentang pemberdayakan keluarga sistem keuangannya dari semua ini sudah dapat di simpulkan, dari Mitra ini sudah dapat berjalan sesuai dengan pentunjuk dari Tim PKM. Sedangkan untuk pelaksanaan dalam dari Tim Program PKM usaha Mikro kue jepit dolar di Sidoarjo sampai dengan penyusunan laporan Akhir berjalan dengan baik dengan dan lancar.

\section{Saran}

Diharapkan kepada para Mitra bilamana terdapat permasalahan terkait dengan Tim program PKM usaha Mikro kue jepit dolar di Daerah sidoarjo, dari tim PKM Usaha mikro siap untuk membntunya.

\section{Ucapan Terimakasih}

Terima kasih kami ucapkan kepada Direktorat Penelitian dan Pengabdian Kepada Masyarakat Direktorat Jenderal Pendidikan Tinggi Kementerian Pendidikan dan Kebudayaan yang telah mendanai pelaksanaan program PKM ini sehingga pelaksanaan kegiatan ini dapat berjalan dengan baik dan lancar.

\section{DAFTAR PUSTAKA}

Ahmadi, Fuad, (2011). Karakteristik Teknologi Tepat Guna dalam Industri Skala Usaha Kecil dan Menengah di Jawa Timuri. Surabaya: Makalah yang disampaikan dalam rangka pelatihan produktivitas usaha kecil di Unesa. Tanggal 26 Juli tahun 2011.

Kotler, Philip, (2013). Marketing Management. Engelwood Cliffs: Prentice Hall International Inc. A Division of Simoon and Scuster. 
Nyoman, Sutantra I, (2011). Produktivitas Sistem Produksi dan Teknologi. Surabaya: Makalah yang disampaikan dalam rangka pelatihan produktivitas usaha kecil di sidoarjo. Tanggal 26 Juli tahun 2011

Subanar, (1912). Permasalahan Usaha Kecil Menengah. Surabaya: Dinas/Kanwil

Perindustrian Jawa Timur.

Peraturan Pemerintah Nomor 17 Tahun 2013

Philip Kotler, Manajemen Pemasaran Analisis, Perencanaan, Implementasi Dan Pengendalian, Lembaga Penerbit Fakultas Ekonomi Univ. Indonesia, Edisi 15, Jakarta, 2005

Lee J. Krajewski Dan Larry P. Ritzman, Operations Management Strategy And

Analysis, Addison Wesley Publishing Company, 2012 